\title{
Supporting Inclusion and Family Involvement in Early Childhood Education through 'ISOTIS': A Case Study in Greece
}

\author{
Anastasia Gkaintartzi \\ University of Thessaly \\ Volos, Greece \\ Evi Kompiadou, Roula Tsokalidou and Konstantinos Tsioumis \\ Aristotle University of Thessaloniki \\ Thessaloniki, Greece \\ Konstantinos Petrogiannis \\ Hellenic Open University \\ Patras, Greece
}

\begin{abstract}
This article presents a case study, conducted in the Greek educational context, as part of the European collaborative project, called "ISOTIS", funded by the European Union, including 17 partners and 11 countries. The main aim of the case study was the support of students' first languages and cultures through home-based and classroom-based activities, family involvement and the professionalization of teachers using ICT environments in early childhood education. In this paper, we particularly focus on aspects of home-school partnership, as promoted through the support of children's heritage languages and cultures, drawing from the perspectives of the parents, teachers, and professionals, who participated in qualitative, semi-structured interviews and focus groups. The research findings show that homeschool partnership was fostered through the inclusion and support of the children's languages and cultures, the affirmation of their identities and the empowerment of their 'voices' and capitals. Last, they highlight that family involvement has a multiple impact not only for bi/multilingual families and their children, but also for teachers and all parts involved, shown to be benefited in a multidimensional way.
\end{abstract}

Keywords: parental involvement; multilingualism; early childhood education; ISOTIS 


\section{Introduction: The ISOTIS project}

'ISOTIS'1 : 'Inclusive Education and Social Support to Tackle Inequalities in Society' is a collaborative project funded by the European Union, which includes 17 partners and 11 countries. In Greece, the Hellenic Open University is the partner institution participating in the ISOTIS consortium. The project started in January 2017 and was completed in December 2019. ISOTIS aims to contribute to effective policy and practice development at different system levels to reduce educational inequalities and contribute to the equality and effectiveness of educational systems, through examples of innovative practices and original educational tools and interventions. A key question for the ISOTIS project is how disadvantaged groups adapt to cultural and linguistic diversity and how they are affected by local and national integration policies and influence educational inequality.

The ISOTIS project addresses the challenges raised by the cultural and linguistic super-diversity of European society and educational settings. Its main goals regard the desired contribution to: a) implementing effective programs for parents and families with different cultural and linguistic backgrounds, b) increasing and innovating inclusive and effective curriculum and pedagogy in early childhood and primary education and c) building professional development of key social agents such as teachers and other professionals.

Concerning its research approach, a three-step procedure was followed. First, an inventory of proven or potentially effective and promising interventions on curriculum, pedagogy and/or school social climate was created. The interventions targeted immigrant, Roma, and low-income children attending early childhood education (ECE) and primary education. Specifically, over 500 interventions were identified in eight European countries and 78 interventions were analysed (Aguiar et al., 2017). Secondly, based on the national inventories created by the participating countries, one ongoing intervention for each country was selected, which met (most of the) following criteria: (a) explicit first and/or second language support, (b) explicit family involvement, and (c) ICT (Information and Communication Technology) activities. These interventions were selected for in-depth case studies to identify effective characteristics and to generate concrete recommendations for the development and implementation of interventions at the classroom or school level, aiming at tackling educational and social inequalities. In this second stage of ISOTIS, seven in-depth case studies of curriculum, pedagogy, and/or social climate interventions were conducted in seven European countries (England, Germany, Greece, Italy, the Netherlands, Poland and Portugal) from distinct geographic regions, diverse in their income levels, research traditions, education and welfare systems and immigrant

\footnotetext{
${ }^{1}$ In Greek 'ıótns (pronounced "eesótis" in English) means equality, evenness, fairness, parity. In alignment with the Greek term, ISOTIS builds on the strengths and potential of culturally and linguistically diverse families, by giving them a voice in how to adapt early education systems and support services. The central goal of the project is to combat inequalities and increase inclusiveness (from the official site of ISOTIS project: http:/ / www.isotis.org).
} 
integration policies (Aguiar \& Silva, 2017). As a third step, a virtual learning environment aiming to support school professionals in developing cultural awareness and plurilingual competence among children (and families) was developed, using ICT (Vasileiadis et al., 2020).

Regarding Greece, the participating national team selected an intervention in the Greek context, from the National Inventory of Curriculum, Pedagogy, and Social Climate Interventions Tackling Social and Educational Inequalities, entitled: "Pedagogical utilization of linguistic and cultural diversity at kindergarten" (for more details, see Kompiadou, 2013). This intervention was considered as a suitable and appropriate case for the needs of the project and consistent with the positive elements and strengths-based approach of ISOTIS. The selected intervention targeted children attending center-based early childhood education settings and was selected as a promising and effective intervention tackling educational inequalities through curriculum design and implementation, classroom practices, and/or school social climate, in early childhood education.

In this paper, we present the case study, which was based on the selected intervention and was conducted in the Greek context, as part of the ISOTIS research stage of in-depth case studies (Kompiadou et al., 2018). The goal of the case study was to describe the key success features and the main facilitators of the intervention in question. By identifying the success features and facilitators we could add to the current scientific knowledge, contributing to transferable solutions on how to promote inclusiveness and equity in the classroom. Also, we could inform teachers, researchers, practitioners, and policymakers on potential paths to move the field forward (Aguiar \& Silva, 2017). In this paper, we particularly focus on aspects of home-school partnership and parental involvement, since this issue, emerged as a key success feature from the research data of our case study.

\section{The Greek Context of Immigration and Education at a Glance}

Migration has been a major socio-political issue in Greece since the 1990s, at first, in the case of immigrants mostly from Albania, neighboring Balkan countries and countries of the former Soviet Union while since the mid-2000s to a lesser extent from Asia, Middle East and sub-Saharan Africa (Gropas \& Triandafyllidou, 2005). Since 2015, refugee flows have been intensified by the Syrian war, forcing over one million people to enter the country and resulting in one of the greatest refugee and most importantly humanitarian crisis of our time (Zambeta et al., 2019). The complex socio-political context of migration in Greece has posed a major challenge for the Greek educational system and policy. Official educational policies responding to multiculturalism in Greek schools have made some important steps, since the early immigration years, to support the inclusion of immigrant children, moving gradually from assimilationist to more inclusive policies (Gkaintartzi, Kiliari, \& Tsokalidou, 2015). Yet, despite the positive steps, the children's bi/multilingualism remains largely 'invisible' in the Greek state school (Gkaintartzi \& Tsokalidou, 2011; Tsokalidou, 2012) while current educational policies and practices are mostly monolingual without taking into account the multilingual and translingual realities of these children. 
The inclusion and support of children's home languages in school education is still a highly controversial and ideological issue since teachers' language practices and beliefs are shown to be oriented toward monolingualism. (Gkaintartzi et al., 2015; Gkaintartzi et al., 2019).

Concerning interventions and research programs aiming at the inclusion of immigrant students, many steps forward have been made, especially in the last 10 years (2007-2017), since drawing from the National Inventory conducted for ISOTIS, a considerable number (i.e. 56) of promising and effective interventions, according to ISOTIS criteria, are identified and recorded. These interventions, targeting early childhood and primary education in Greece, aimed at tackling inequalities experienced by children with immigrant/ethnic minority background (OECD, 2015) or from low SES (socioeconomic status) families, while also promoting multilingualism, multiculturalism, inclusion and family involvement (Aguiar \& Silva, 2017). However, there is still a lot to be done in the field of multilingualism and school language education, to promote teaching policies and practices, which value and support the children's home languages and cultures in school teaching/learning while, in particular, the issue of parental involvement within this context becomes a highly complex and multidimensional issue.

In Greece, parental involvement has been minimally investigated and research interest in this issue is very recent while not long ago it was included in the official educational policy agenda (Penderi \& Petrogiannis, 2013). As a result, a rather superficial and typical relationship between parents and schools has been recorded in the relevant literature (Penderi \& Petrogiannis, 2013). Regarding immigrant families, research in parental involvement and school - family communication is even scarcer; however, research data show that immigrant parents' involvement in their children's education is disempowered by dominant school policies and practices, which exclude and disregard their linguistic and cultural capital (Androulakis et al., 2017). Given that inclusion and multilingualism/multiculturalism in Greek education are major issues requiring further development while parental involvement among immigrant parents needs to be more systematically addressed, researched and supported, we believe that the ISOTIS project and the case study presented can make an important contribution.

Practices and interventions for supporting children's home languages and cultures while also involving their families, for increasing language awareness and implementing translanguaging pedagogy in classrooms are needed to promote inclusive education. ISOTIS is a project which involves innovative practices, educational tools and interventions aiming at reducing social inequalities and reinforcing inclusion. 


\section{Literature review}

\section{Home-school relations and parental involvement}

In this section key theoretical concepts, which provide the framework of our case study, are discussed and reviewed. First of all, multilingualism is a central concept to the research. The value and inclusion of the students' linguistic and cultural backgrounds in the teaching process is an important factor for their learning and overall development. School language policies and home-school communication plays an important role in supporting immigrant families' multilingualism by communicating the value and respect for their languages and cultures, creating a space for them in the school curriculum, involving actively the parents and giving them 'voice' in the school context (Androulakis, et. al., 2017).

The family is the most influential micro-system affecting children's development especially focusing on the first years of a child's life (Anders et al., 2017). A further micro-system with universal relevance in Europe is any form of Early Childhood Education and Care experience, such as preschool settings (Anders et al., 2017). Positive connections among these two systems refer to the mesosystemic level and consist one of the most powerful forces that boost their effectiveness in child development and learning. Parental involvement is an umbrella term that delineates these connections on the part of the family, describing parents and other family members' behaviors, practices and relationships to foster children's development and learning.

Family socio-economic background and the quality of the home environment are positively related to the quality of parental involvement conceptualized as the affective blueprint of parents' engagement in children's learning (Petrogiannis \& Penderi, 2014). Moreover, parental involvement in schooling is positively associated with many benefits for students (Gracia, 2014). Taking into account that immigrant background children are sometimes disadvantaged compared to native children in terms of educational participation and outcomes (Riederer \& Verwiebe, 2015), supporting parental involvement may be a key factor to promote their adjustment and school success. Additionally, including and building on cultural values of origin in school plays an important role in children's school success (Nauck \& Schnoor, 2015) and parents can be valuable partners in relevant activities. The socio-cultural interaction between various origin immigrants and receiving countries students and families can make a large difference concerning migrant-native gaps in education (Levels \& Dronkers, 2008; OECD/European Union, 2015).

Parental involvement practices refer to the type and amount of participation a parent has when it comes to ECEC, schooling and the child's life. Epstein and Sheldon (2006, p. 118) broaden the term "parental involvement" proposing school, family and community partnerships arguing that all three groups share the responsibility for learning and developing children and focusing on their interrelationships. Parental involvement in early learning has a greater impact on children's well-being and achievement than any other factor such as parental education or family income while accordingly states are asked to adopt 
evidence-based interventions to support good parenting (Anders et al., 2017). These interventions should emphasize sharing responsibility between families and school and recognize that schools play an important role in encouraging parents to become actively involved, while this involvement becomes an important element in promoting inclusion and supporting the children's funds of knowledge (González et al., 2005).

Parental involvement in the case of families with immigrant and refugee background is an important, supportive factor for the academic development of students of immigrant origin (Jeynes, 2003; Kao, 2004; Kim, 2002; Martinez et al., 2004) their motivation and well-being. Empowering parents in family engagement and involvement is an important element in promoting inclusion, combating social inequalities in education and improving the children's learning outcomes (Block et al., 2014). The concept of parental involvement is multidimensional, culturally oriented and ideologically loaded, especially in the case of immigrant parents, while aspects of language hierarchies and "legitimacy" of specific linguistic and cultural capitals may restrict their access and silence their voices, positioning them in further disempowering categories (Androulakis et al., 2017). For bi/multilingual families of immigrant background, support for first language development in early and middle childhood may face obstacles, challenges and ambivalence (Pauwels, 2005; Curdt-Christiansen, 2009; Kirsch, 2012). There is, however, empirical evidence that good practices that enhance parental involvement and educational interventions to support and engage bi/multilingual families in school education promote the establishment of trusting home-school relationships and partnerships and enhance students' learning and inclusion (Mary \& Young, 2017).

Indicatively, "identity texts" created by children and parents give space to their voices as they produce authentic personal narratives. Cummins and Early (2011, p. 3) describe identity texts as "the products of children, creative works or performances, carried out within the pedagogical space orchestrated by the classroom teacher". The "text" is related to the immediate and also to the wider socio-cultural context, focusing on the cultural and linguistic background that comes to the foreground (Cummins, 2001; Tsokalidou, 2012) facilitating and encouraging translanguaging (Tsokalidou, 2017). Thus, identity texts can create spaces for translanguaging practices, through which children and parents can express themselves and their multilingual realities, using all their linguistic resources and a range of semiotic means.

\section{The Case Study: Methodology}

The case study was in line with the general ISOTIS goals, aiming at contributing to family support, curriculum, professional development and inter-agency coordination. Specifically, the main aim of the case study was to identify and describe the success features and facilitators of the selected intervention, as well as the obstacles experienced, while also describing and analyzing some types of solutions. The general goal of the selected intervention had been to support 
children's multilingualism and cultures with the use of pedagogical tools that promote diversity. These tools and activities included literary texts and multilingual material, biographical narratives and identity texts, ICT use, works of art, photographs, films, recordings, questionnaires, interviews with parents and children.

In this research, the case study attempted to apply this material in educational activities in four kindergarten classrooms. We selected the methodological approach of the case study, as it is a common method in qualitative research that locates the researcher in the real world (Creswell, 2013; Denzin \& Lincoln, 2011). A case study is an approach to explore a phenomenon within its context (Creswell, 1998) and as a unit of analysis (case) it observes the process, the time, the place within it. Furthermore, multiple-case studies can be used to predict similar results, as a literal replication, contributing to the understanding of the whole phenomenon (Yin, 2003). Thus, we conducted an exploratory, multiplecase study, as it explored more than a single case, using a variety of data to answer "when", "how" and "why" the cases become significant to the research purposes (Baxter \& Jack, 2008). Through in-depth, semi-structured interviews and focus groups with teachers and other key staff members as well as parents and via analyses of children's perspectives and productions and observation, it aimed to identify and describe the success features and facilitators that are important in promoting inclusion, equality, and belongingness in education.

The case study was implemented from April to June 2018 in four pre-school classrooms, in Western Thessaloniki, Greece, with 65 students, aged 4-6 years and with the contribution of 5 teachers. Western Thessaloniki was selected as the research setting, as it is a site in Greece that hosts families from disadvantaged backgrounds. It is noted that migrants (from third countries) living in the Municipality of Thessaloniki come mostly from Albania and countries of the former USSR. A prior children's study had been conducted to elicit the children's prior perceptions, reflecting on and discussing their school experience in terms of inclusion, well-being, and acknowledging/respecting differences, through focus group/circle time discussions.

The five teachers (see Table 1), who implemented the activities in their classes, were interviewed in a focus group at the end of the school year. One of them was a researcher in the ISOTIS project for the Greek team and was responsible for organizing and observing the process of implementing the activities. The coordinator (project's academic supervisor on behalf of the Aristotle University of Thessaloniki), the site coordinator (director of the school) and the researcher participated in individual interviews. The researcher was interviewed by another member of the ISOTIS national research team. 
Table 1: Profile of the professionals and teachers

\begin{tabular}{|l|l|l|l|}
\hline \multicolumn{1}{|c|}{$\begin{array}{c}\text { Role of } \\
\text { Professional }\end{array}$} & \multicolumn{1}{c|}{$\begin{array}{c}\text { Teaching } \\
\text { experience }\end{array}$} & \multicolumn{1}{c|}{ Specialty } & \multicolumn{1}{c|}{ Site } \\
\hline Coordinator & $\begin{array}{l}\text { 29 years total, 18 } \\
\text { years in Aristotle } \\
\text { University of } \\
\text { Thessaloniki (AUth) }\end{array}$ & $\begin{array}{l}\text { Professor in } \\
\text { Sociolinguistics, } \\
\text { Coordinator of } \\
\text { "Polydromo" }\end{array}$ & $\begin{array}{l}\text { Aristotle } \\
\text { University of } \\
\text { Thessaloniki }\end{array}$ \\
\hline $\begin{array}{l}\text { Preschool } \\
\text { Teacher- } \\
\text { Researcher }\end{array}$ & $\begin{array}{l}\text { 3 years in private } \\
\text { and } 20 \text { years in } \\
\text { public schools }\end{array}$ & $\begin{array}{l}\text { Ph.D. candidate in } \\
\text { AUTh }\end{array}$ & $\begin{array}{l}\text { Preschool class in } \\
\text { Western } \\
\text { Thessaloniki }\end{array}$ \\
\hline $\begin{array}{l}\text { Preschool } \\
\text { Teacher- Site } \\
\text { coordinator }\end{array}$ & $\begin{array}{l}\text { 22 years in public } \\
\text { schools }\end{array}$ & $\begin{array}{l}\text { Postgraduate degree } \\
\text { in intercultural } \\
\text { education }\end{array}$ & $\begin{array}{l}\text { Preschool class in } \\
\text { Western } \\
\text { Thessaloniki }\end{array}$ \\
\hline $\begin{array}{l}\text { Preschool } \\
\text { Teacher A }\end{array}$ & $\begin{array}{l}10 \text { years in private } \\
\text { and } 17 \text { years in } \\
\text { public schools }\end{array}$ & Educational training & $\begin{array}{l}\text { Preschool class in } \\
\text { Western } \\
\text { Thessaloniki }\end{array}$ \\
\hline $\begin{array}{l}\text { Preschool } \\
\text { Teacher B }\end{array}$ & $\begin{array}{l}10 \text { years in public } \\
\text { schools }\end{array}$ & $\begin{array}{l}\text { Intercultural } \\
\text { training }\end{array}$ & $\begin{array}{l}\text { Preschool class in } \\
\text { Western } \\
\text { Thessaloniki }\end{array}$ \\
\hline $\begin{array}{l}\text { Preschool } \\
\text { Teacher C }\end{array}$ & $\begin{array}{l}\text { 23 years in public } \\
\text { schools }\end{array}$ & Educational training & $\begin{array}{l}\text { Preschool class in } \\
\text { Western } \\
\text { Thessaloniki }\end{array}$ \\
\hline
\end{tabular}

Three parents (see Table 2) with a migrant background participated in individual interviews respectively. In sum, one focus group with the three preschool teachers (A, B, C) was conducted, three interviews with the other professionals and three with the parents.

Table 1: Profile of parents

\begin{tabular}{|c|c|c|c|c|c|c|c|c|}
\hline Code & Age & Sex & Education & $\begin{array}{l}\text { Countries } \\
\text { of origin }\end{array}$ & $\begin{array}{l}\text { Family } \\
\text { status }\end{array}$ & $\begin{array}{l}\text { Number } \\
\text { and age of } \\
\text { children }\end{array}$ & Languages & Employment \\
\hline A. & 35 & F. & $\begin{array}{l}\text { Primary } \\
\text { school }\end{array}$ & $\begin{array}{l}\text { Born in } \\
\text { Georgia, } \\
\text { her father } \\
\text { from } \\
\text { Russia, her } \\
\text { mother } \\
\text { from the } \\
\text { eastern } \\
\text { Black Sea } \\
\text { Region of } \\
\text { Turkey }\end{array}$ & married & $\begin{array}{l}2 \\
\text { daughters, } \\
8 \text { and } 10 \\
\text { years old }\end{array}$ & $\begin{array}{l}\text { Russian } \\
\left(1^{\text {st }}\right) \text {, } \\
\text { Greek, } \\
\text { Georgian } \\
\text { Pontiac (a } \\
\text { little) }\end{array}$ & unemployed \\
\hline B. & 38 & M. & High school & $\begin{array}{l}\text { Born in } \\
\text { Albania, } \\
\text { both } \\
\text { parents } \\
\text { from } \\
\text { Albania }\end{array}$ & married & $\begin{array}{l}1 \text { daughter, } \\
8 \text { years old }\end{array}$ & $\begin{array}{l}\text { Albanian } \\
\left(1^{\text {st }}\right), \\
\text { Greek, } \\
\text { Italian (a } \\
\text { little) }\end{array}$ & retired \\
\hline
\end{tabular}

2 'Polydromo' is an inter-university group focusing on issues of language contact and bilingualism. For more information please visit: www.polydromo.gr 


\begin{tabular}{|l|l|l|l|l|l|l|l|l|}
\hline C. & 32 & F. & University & $\begin{array}{l}\text { Born in } \\
\text { Serbia, } \\
\text { both } \\
\text { parents } \\
\text { from Serbia }\end{array}$ & married & $\begin{array}{l}2 \\
\text { daughters, } \\
5 \text { and } 8 \\
\text { years old }\end{array}$ & $\begin{array}{l}\text { Serbian } \\
\left(1^{\text {st }}\right), \\
\text { Greek, } \\
\text { English }\end{array}$ & unemployed \\
& & & & & \\
\hline
\end{tabular}

In line with the multidisciplinary approach adopted by ISOTIS employing multiple research methods, the case study involved the use of observation, focus group and individual interviewing, document analysis, expert consultation. The open methods of the qualitative interviews and case studies allow interviewees' voices to be heard (Creswell \& Clark, 2007) and thus were selected as research tools for the case-study. All codes of conduct were respected and the anonymity of the participants was ensured.

\subsection{Method of Data Analysis}

Interviews and conversational material was transcribed and analyzed with the use of Content Analysis, which is a suitable qualitative method to be used with a small sample (Clarke \& Braun, 2013). Specifically, thematic content analysis was employed which focuses on meanings or themes that use the text as a "window into experience" (Ryan \& Bernard 2000, p. 769). The themes, that were used as a guide for interviews and focus groups and as thematic categories for the data analysis were: (1) history of the intervention, (2) key activities, including information regarding their type, structure, and content; location and timing; professionals responsible for implementation, and participants, (3) features of success, focusing on unique intrinsic features and strengths of the intervention, (4) facilitators, that is, (external) factors that contribute to the success of the intervention, (5) barriers and how to overcome them, 6) perceived impact for key actors, (7) innovative features of the intervention, (8) lessons learned and future directions, (9) country-specific themes.

In this paper we focus on parental involvement and home-school partnership, which emerged from our data analysis as a key feature of success, along with language support and inclusion of immigrant children's home languages and cultures. The research data presented are based on the perspectives of the parents, the teachers, and professionals, drawing from focus group and interviews.

\section{Findings}

In this section the findings of the case study are presented in the thematic categories, which emerged from the data analysis.

\subsection{Parental involvement and the role of families}

The role of families is considered to be very important since parental involvement is shown to be among the factors that improve the educational process and to function as a link between the school and the community. As the teacher argues 


\begin{abstract}
"Very important, parental involvement has very positive results both for children and for the parents' role, but also for the relationships between them and the class teacher. The active participation of parents increases the teachers' motivation and their educational role at the same time and enhances the children's participation and their self-esteem" " (Teacher A)
\end{abstract}

What is important to point out here is the reciprocity and mutual relationship between parental involvement and teacher motivation and role; parental involvement is considered by this teacher to affect positively their educational role and motivation. This is a very empowering teacher perspective on parental engagement considering that it is a concept mostly addressed from the view of its impact either on the children's development and/or the parents' role and efficiency (Fan \& Tsen, 2001; Emerson et al., 2012).

According to the site coordinator: "Engaging parents and recognizing the value, the culture, the cultural background and the ecosystem of families is one of the additional strategies implemented by the kindergarten as well as the connection with the community". Strong personal relationships with the family and a stable pedagogical staff are among the success factors which are reported. "When all children and parents are happy sharing stories from their various backgrounds and feel happy and lucky to have been involved in this project with the specific teacherresearcher" (Coordinator).

Characteristically, a parent in his interview talks about his own experience within the implementation of the case study against racism and is in line with the inclusive practices that ISOTIS promotes. He states:
"Yes, I say that people should love other people and everyone's culture. We live in a reality, in globalization. A Greek or an Albanian cannot say that 'We do not want Greeks here' or 'We do not want Albanians or others here'. 'It is not possible. If it were so, it would be like communism, with closed borders and just: 'you live in here'. People now move, go from one side to another... there should be no such thing, racism, this dividing line between people..." (Parent B).

This parent argues against racism and closed borders and supports the importance of contact between different cultural groups since this is how the sociolinguistic reality is with people on the move and no divisions.

Accordingly, the coordinator states: "Students and their families acquire a deeper and meaningful understanding of linguistic and cultural variation and that migrant parents feel an important part of the school process". The father's words, below, in this direction, are very characteristic as he sees teachers as ambassadors among children and the school regarding issues of equality and social justice:

"... the teacher treated all children the same way. The children were equal to each other. It was not that the one comes from Albania, the other from Russia and another from Greece. This is why I say that teachers and kindergarten teachers are the ambassadors, because children learn from them. They learn how to look to each other, how to feel nice among them without offending or without feeling as being in an inferior position, like: 'I come from Albania and I cannot be equal to a Greek'..." (Parent B). 
This parent reflects on his experience with the case study and focuses on the important role teachers play in promoting equality in the classroom. The mother below talks about the benefits of contact and building relationships among parents and schools:

"The positive points. There was a very good atmosphere among children and parents ... First of all, it helped me to open up more, to come closer to the other parents, with whom our relationship still holds up to today. All of this was positive. For my children as well, although it's easier for kids than for grown-ups to adjust, it was very nice" (Parent A).

She reflects on the positive impact of bringing parents together, immigrants and non-immigrants, with the school, which is seen to facilitate open communication, connection and a sense of belongingness.

\subsection{Language support}

Extensive language support and sensitivity to the local context and culture have emerged as key elements of the program, as a teacher argues:

"The children came into contact, at least in our class, with languages that they had never heard before and they impressed them, that is, the Arabic language impressed them both with its writing and its accent. While they had heard Albanian before e. g. Arabic made a great impression on them and that is a benefit. They had ... they knew more about European languages, so they now faced stereotypes about people and languages unknown and they enriched their knowledge" (Teacher A).

Another teacher adds:

"Besides, the children, who had never referred to their languages [before], were allowed to feel more comfortable in class concerning their origin and language. The schoolgirl who heard her language [spoken in class] showed that she enjoyed it and she was more expressive after that" (Teacher B).

Apart from its benefits for supporting children's multingualism, multilingual awareness and identities, positive impacts are also found for empowering families' language views and practices, which -as shown- can be affected by such school interventions and practices: "I have found that it can help parents too, to change their impressions. Some families support their origin and others do not. The school can play a role in all that. To help with their inclusion" (Teacher C). In the case study, which focused on the first languages and cultures of the children's families, their funds of knowledge (González et al., 2005), it was important to foster communication and interaction with parents of the dominant culture.

"I think it's successful because... I was born in another country and there were a lot of nationalities there, and I am used to listening to another language, hanging out with people of another nationality and I like it that we communicate here as well, we learned how to communicate with people from Albania, Georgia..." (Parent A). 
The same mother goes on to report the change she sees in herself and her children:

"I think it worked positively for the parents we had the most contact with, it brought us together even more, and as for the children... I don't know, my children are more liberated now that they speak another language. We didn't use to be like that. When we first came we talked in a very low voice so as not to... we were embarrassed. Now my children aren't... For example, $A$. is not at all embarrassed to be speaking Russian... and we owe all this to the program somehow. Because you told us: Speak Russian at home, let the children learn... the children speak Russian and aren't ashamed, it's not like in the past!" (Parent A).

It emerges from her words that her children and herself were empowered to 'voice' their languages, their identities were affirmed (Cummins, 2001) while this is felt and expressed as a sense of 'liberation', as feeling free to speak, practice and celebrate the benefits of multilingualism. The researcher argues that:

\begin{abstract}
"It benefited not only the bilingual children but all the children in the class who were equipped with the qualifications and the perspective needed to enable them to become citizens of the world. The children of the host country, who are not linguistically and culturally diverse, are treated by the educational system with homogeneity despite their visible and non-visible differences, from this cultural exchange they are encouraged to acquire a meaningful contact and knowledge of the languages and cultures that are next to us mainly in our schools".
\end{abstract}

Accordingly, this mother's words show the importance of highlighting the linguistic and cultural heterogeneity of the classroom: "It presented other languages to children... To children that could only speak Greek, I think they took it more... not as something huge... something strange. They took it easier and accepted it as something normal" (Parent A). This mother talks about the pride that both she and her daughter felt through the implementation of the case study since for her it is the first time that someone is with their languages and cultures; with who they are:

\begin{abstract}
"She felt very proud (her daughter) and I felt too; because we are concerned with it (i.e. their language/culture), I do not know if anybody else has done it before. It was shown how you deal with all the children.... These things... they are from Albania, and we are from Serbia and the other one is from Georgia... I remember the wedding we worked on with different songs from all countries of the children" (Parent C).
\end{abstract}

The coordinator states: "It addresses the need to cater for the smooth integration of migrant background children into preschool education and the development of a school context of creative language and culture contact". According to the site-coordinator, "It fulfills the need to develop a climate of acceptance and trust" and according to the teacher: "I believe that it will touch issues that are important but also sensitive to a certain extent" (Teacher B). The interviewees argue that focusing on multiculturalism and multilingualism has had benefits for everyone involved in 
the educational process, thus strengthening not only immigrant identities but also those of the dominant culture, addressing and building on the aspect of the global citizen; their global identity. Diversity was presented as natural, as the norm through the activities implemented in the kindergarten. The meaningful contact of languages and cultures in the kindergarten classroom comprises, thus, an inclusive practice and a creative educational process constructing a school climate of acceptance and trust between the school and the family.

\subsection{Obstacles}

The obstacles, which emerged from the research data, highlight different aspects of the concept and process of home-school partnership. "The reduced participation, indifference from some parents, limited school time" was mentioned by a teacher (Teacher A) while another teacher also stated: "One of the problems is the lack of time from the part of the parents" (Teacher C). It seems that parental involvement may be considered by teachers, even in the context of the case study, as the sole responsibility of parents and therefore their reduced participation may be interpreted directly as their 'indifference' or ' lack of time'. A teacher suggests providing incentives to increase parent involvement that is in line with modern media and the power of mass media that seem to influence parents as they are directed towards competitive activities:

"Something that would have been competitive if we presented that the school is involved and we need your contribution perhaps. In the eTwinning program when we made a poster and we had to vote, they involved themselves in the process, respectively last year in an environmental program. I saw them to be more interested in something like that. The influence of the media is apparent here" (Teacher A).

Parental awareness is considered important: "Few are already aware of the migrant or refugee issue in which they would show greater interest. The issue is also political ..." (Teacher B), therefore similar actions are suggested in this direction: "Through corresponding programs like this case study and awareness-raising actions" (Teacher C)". Also, the same teacher reflects on the activation of parents to participate: "Parents, however, are influenced by one another. In a positive direction, for participating in the activities, the incentive is given so that someone else does something too. Incentives need to be given" (Teacher B). Participation should not be taken for granted. The teachers report as a disadvantage the reduced parental involvement in parents' gatherings and informative meetings.

"It would be very important if all families were involved. I often do not get a response from everyone. In the meetings we hold for providing information about the program, all previous programs, and afternoon meetings so that they can come, half of them attend and we get a response from fewer of them, especially at the end of the year" (Teacher A).

Accordingly, another teacher reports: "Their participation is very important, we do not always have their response, I agree" (Teacher B). Apart from that, it is reported that sometimes they experience negative feelings not only regarding their role but also towards the school as an institution: "Sometimes there is a depreciation of 
the school in general" (Teacher A). Some parents think that the kindergarten does not have the same requirements as the other school levels" (Teacher C). Addressing such situations requires careful management and good organization of educational practices in terms of the school planning: "When a program starts from the beginning of the school year and focuses in-depth, then participation is increased" (Teacher A). Deep knowledge of the educational framework and an approach that meets the needs of all the parents involved are also considered important.

According to the coordinator, intercultural competence is a qualification and a skill to cope with such phenomena as well as the corresponding material:

"As members of Polydromo group all program developers had a deep and long-standing understanding of migrant issues, had already formed important bonds with migrant families and communities and had access to various resources that were developed within the group's initiatives" (www.polydromo.gr)

As the site coordinator argues they had difficulties:

"...to inform the few parents who did not speak Greek. Language has been an obstacle to our efforts to inform and persuade other-languages speaking parents to get involved in the program. In this case, we asked for help from parents who knew the language of these families. So they functioned as interpreters, moreover as mediators".

The potential for the parents' participation in the school context, apart from their invaluable contribution to translation/interpretation processes, involves also the mediation of their funds of knowledge (González, et al., 2005) which is an important aspect of parental involvement and an empowering procedure for themselves too. For the researcher, the difficulties seem to relate to the personal exposure of people which always entails a risk, as well as when referring to historical events that are never neutral:

"Dealing with the identities of people in depth has a tremendous educational interest, it constitutes a link between the family and the school environment. Personal exposure is always a difficult and sometimes sensitive issue, it touches the personal sides of the individual, and it must be done within a secure framework of communication and trust. This is not built overnight, but it is part of the school culture in which the school invests".

\section{Discussion}

Home-school partnership, as a success feature to promote inclusion and equality, is fostered through the inclusion and support of the children's languages and cultures, the affirmation of their identities, the empowerment of their 'voices' and understanding of their capitals. Language support and homeschool partnership are seen to be two interrelated key factors in designing and implementing interventions which promote inclusion, equality, and belongingness in education. It emerges from the data analysis that investing in good communication between the school and the families, which is based on 
providing parents with clear information about school practices, procedures and expectations, interacting and engaging in ongoing contact with them, is considered a key factor facilitating their involvement. Such communication requires intercultural skills on the part of the teachers, which play an important role in their professional development and teacher identity. Communication and trust are two concepts that mediate home-school communication and provide the basis for their partnership. The researcher, in the extract below, reflects on the practices for parental involvement, which were employed in the case study such as the use of personal narratives shared publicly with ICT and highlights the political and critical role schools have to play in touching upon historical and social issues, which can also motivate and engage parents.

"Incentives were given regarding participation. The emergence of personal stories e.g. in an attractive way, of the students' family trees using the computer, or their exhibition, open to the public, within the school. Sensitive historical issues were smoothed through discussion and dialogue. The parents realized that in the school context the objective depiction (to the degree that it can be objective) of historical events is necessary. Experiences remain alive and narratives always carry this risk, to capture the narrator's eye".

Cultural and linguistic exchange between the school and the family is a constituent part of the educational process against social exclusion and isolation. The importance of teacher training and professional development in designing and implementing similar (to the case study) practices and interventions is also shown, as well as its positive impact on the teachers' own professional identity. According to the coordinator, the evaluation of the case study points to:

"The importance of sharing knowledge on different languages and cultures, the equal importance of all languages for their speakers, the importance of languages for identities for all involved in the school process (teachers, children and parents), the importance of multilingualism and multiculturalism for educational and social contexts alike".

Knowing, sharing and investing in all languages and cultures are seen to be key elements in school interventions and practices aiming to tackle inequalities and promote inclusion.

The parents also evaluated the program by highlighting positive impacts regarding themselves, their children and the community. Among the positive outcomes, they included effective communication among all parts, recognition and promotion of linguistic and cultural heterogeneity and the use of technology. In the context of the case-study, coexistence with other cultures and interaction has been reinforced while self-esteem and self-confidence among children and families have been strengthened as they were encouraged to participate and have a voice in the school curriculum and context. The case study and the activities implemented have equipped the children and their families with the necessary commitment and engagement to the educational 
process, by providing space for the languages and cultures and reaching out for them, building on an open, two-way, true communication.

Family narratives, stories and other "identity texts" created by children and parents were used to give space to their voices as they produce authentic personal texts. This process has strengthened home-school relationships, by empowering parents to participate in their children school learning and life and by also building on teachers' intercultural competence, awareness and 'openness' (Magos \& Simopoulos, 2009). It emerges that the case study had a perceived impact for both parts, parents (immigrant and non-immigrants) and teachers, as through the use of multilingual and multicultural activities, they were both actively and responsively engaged in their communication and collaboration as equal partners. The teachers were encouraged to reverse the way of thinking and highlight among school children and their parents the heterogeneity of society and the forms of power that constitute it, to construct more collaborative power relationships (Cummins, 2001) in and out the classroom. By confronting the dominant perceptions of homogeneity and by challenging pedagogical complacency it was attempted to create a place of meaningful understanding and acceptance in school and the community (Androusou \& Askouni, 2007). Thus, the monocultural perspective gives its place to an intercultural perspective, to an extended view and critical stance, through contact and interaction with languages and cultures while also building on teachers' intercultural competence (Magos, 2005; Magos \& Simopoulos, 2009; Tsokalidou, 2017). From the part of the parents, the father's words below reflect a sense of self-confidence, optimism and empowerment coming from the recognition, respect and promotion of cultural diversity seen to be experienced in the case study:

"This means that something is changing. It changes, it matures through time. Now there is the chance for the children! They should now learn that it really does not exist: \{you are like this and I am like that\}. This is racism in everything ... and I call it racism because I am Albanian or the other is Greek, but you can see racism even in fat or thin people, rich or poor. This should be taught by the teachers through education that "difference is nice". Every human is different and unique! We cannot be the same, if we were, we would be clones. As if we had come from a factory" (Parent B).

This 'change' that the parent refers to also highlights the Critical Pedagogy aspect of the case study and the ISOTIS project as a whole, as it managed to actively act upon and make some changes in the school context and climate, which whatsoever had an impact and made a difference for the participants.

\section{Conclusion}

Recognizing and appreciating diversity can be developed through educational practices and interventions, which create cooperative, open environments through the support of children's language and cultures and partnerships with their families. The limitations of our case study need, also, to be taken into account and could be addressed in future research, regarding the number of 
participants and the practices used. Our study focused on four pre-school classes in the Greek context but it could be expanded to more settings, including more participants and practices, to be able to make some generalizations of the findings. Based on our findings, directions for further research may involve future work towards a more equitable, fair, truly and mutually empowering parental involvement through school practices, which promote multilingualism and family involvement, benefiting all parts involved in a multidimensional way. It is important to become aware of and address the obstacles in homeschool partnership, as the further support of connecting parents - immigrants and non-immigrants- with the school is seen to have a positive impact on inclusiveness and belongingness. Implications can also be formulated for similar targeted interventions in schools as well as for teacher training towards the intercultural competence of teachers and professionals in education. Concluding, the case study adds to the existing literature concerning parental involvement and home-school relationships, by showing the multiple impact it has not only for immigrant families and their children, but also for non-immigrant parents, by building on their global citizen identity, for all students, by building on multilingual and intercultural awareness as well as for teachers, by developing intercultural skills and enhancing their professional efficacy.

\section{References}

Aguiar, C., \& Silva, C. (Eds.) (2017). Case studies on curriculum, pedagogy, and social climate interventions tackling inequalities. Report submitted to the European Commission by the ISOTIS Consortium. Retrieved from http://archive.isotis.org/wpcontent/uploads/2019/03/ISOTIS_D4.3_Case-

studies_curriculum_pedagogy_social-climate-interventions.pdf

Aguiar, C., Pastori, G., Camacho, A., Guerra, R., Rodrigues, R., Zurloni, V., Mantovani, S., Penderi, E., \& Tsioumis, K. (2017). Short literature review of main trends and challenges in curriculum approaches, educational practices, and social climate interventions aiming to tackle social inequalities. ISOTIS, Inclusive education and social support to tackle inequalities in society, European Union's Horizon 2020.

Anders, Y., Cadima, J., Evangelou, M., \& Nata, G. (2017). Parent and family-focused support to increase educational equality. Central Assumptions and core concepts. D3.1 Report on literature review WP3. ISOTIS, Inclusive education and social support to tackle inequalities in society. Retrieved from http://www.isotis.org/resources/publications/isotis-publications/

Androulakis, G., Gkaintartzi, A., Kitsiou, R., \& Tsioli, S. (2017). Parents-Schools' communication and Albanian as a heritage language in Greece. In P. P. Trifonas \& T. Aravossitas (Eds.), Handbook of Research and Practice in Heritage Language Education (pp. 521-538). Springer International Publishing. doi:10.1007/978-3319-44694-3_1

Androusou, A., \& Askouni, N. (2007). Taftotites ke eterotites. Eterogenia ke sxolio. [Identities and diversity. Heterogeneity and school]. Athens: YPEPTH, University of Athens. [In Greek]

Baxter, P., \& Jack, S. (2008). Qualitative case study methodology: Study design and implementation for novice researchers. The Qualitative Report, 13(4), 544-559. Retrieved from http://www.nova.edu/ssss/QR/QR13-4/baxter.pdf

Block, K., Cross, S., Riggs, E., \& Gibbs, L. (2014). Supporting schools to create an inclusive environment for refugee students. International Journal of Inclusive Education, 18(12), 1337-1355. doi:10.1080/13603116.2014.899636 
Clarke, V., \& Braun, V. (2013). Teaching thematic analysis: Overcoming challenges and developing strategies for effective learning. The Psychologist, 26(2), 120-123. Retrieved from https://uwerepository.worktribe.com/output/937596/teaching-thematic-analysisovercoming-challenges-and-developing-strategies-for-effective-learning

Creswell, J. (1998). Research design: Qualitative, quantitative, and mixed methods approaches (2nd ed.). Thousand Oaks, CA: Sage.

Creswell, J., \& Poth, Ch. (2013). Qualitative inquiry and research design: Choosing among five approaches. Thousand Oaks, CA: Sage.

Creswell, J., \& Clark, V. (2007). Designing and Conducting Mixed Methods Research. Thousand Oaks, CA: Sage.

Cummins, J. (2001) Negotiating identities: Education for Empowerment in a Diverse Society. Ontario, CA: California Association for Bilingual Education.

Cummins, J., \& Early, M. (2011) Introduction. In: J. Cummins \& M. Early (Eds.), Identity TEXTS, the Collaborative Creation of Power in Multilingual Schools. Sterling, UK: Trentham Books.

Curdt-Christiansen, X. L. (2009). Invisible and visible language planning: ideological factors in the family language policy of Chinese immigrant families in Quebec. Language Policy 8(4), 351-375. doi:10.1007/s10993-009-9146-7

Denzin N. K., \& Lincoln Y. S., (2011). The SAGE handbook of qualitative research. Thousand Oaks, CA: Sage.

Emerson, L., Fear. J., Fox, S., \& Sanders, E. (2012). Parental engagement in learning and schooling: Lessons from research. Report by the Australian Research Alliance for Children and Youth (ARACY) for the Family-School and Community Partnerships Bureau: Canberra. Retrieved from https://www.aracy.org.au/publications resources/command/download_file/id/7/filename/Parental_engagement_in_1 earning_and_schooling_Lessons_from_research_BUREAU_ARACY_August_20 12.pdf

Epstein, J., \& Sheldon, S. (2006). Moving forward: Ideas for research on school, family, and community partnerships. In C. F. Conrad \& R. Serlin (Eds.). SAGE Handbook for research in education: Engaging ideas and enriching inquiry (pp. 117-138) Thousand Oaks, CA: Sage Publications. doi:10.4135/9781412976039.n7

Fan, X., \& Chen, M. (2001) Parental Involvement and Students' Academic Achievement: A Meta-Analysis. Educational Psychology Review, 13(1), 1-22. doi:10.1023/A:1009048817385

Gkaintartzi, A. Mouti, A., Skourtou, E., \& Tsokalidou, R. (2019). Language teachers' perceptions of multilingualism and language teaching: the case of the postgraduate programme "LRM". Language Learning in Higher Education, Journal of the European Confederation of Language Centres in Higher Education (Cercles), 9(1), 33-54. doi:10.1515/cercles-2019-0002

Gkaintartzi, A., Kiliari, A., \& Tsokalidou, R. (2015). 'Invisible' bilingualism - 'invisible' language ideologies: Greek teachers' attitudes towards immigrant students' heritage languages. International Journal of Bilingual Education and Bilingualism 18(1), 60-72. doi:10.1080/13670050.2013.877418

Gkaintartzi, A., \& Tsokalidou, R. (2011). She is a very good child but she doesn't speak: The invisibility of children's bilingualism and teacher ideology. Journal of Pragmatics, 43(2), 588-601. doi:10.1016/j.pragma.2010.09.014

González, N., Moll, L. C., \& Amanti, C. (Eds.). (2005). Funds of knowledge: Theorizing practices in households, communities, and classrooms. New York, U.S.A: Routledge, Taylor and Francis group. doi:10.4324/9781410613462 
Gracia, P. (2014). Fathers' Child Care Involvement and Children's Age in Spain: A Time Use Study on Differences by Education and Mothers' Employment. European Sociological Review, 30(2), 137-150. doi:10.1093/esr/jcu037

Gropas, R., \& Triandafyllidou, A. (2005). Migration in Greece at a glance. Hellenic Foundation (Overview based on the Country Report prepared for the project POLITIS: Building Europe with New Citizens?). Athens: ELIAMEP. Retrieved from http://www.eliamep.gr/wp-content/uploads/en/2008/10/migration.pdf

IOM. (2018). Migration in Greece: a country profile 2018. Retrieved from: https://publications.iom.int/books/migration-greece-country-profile-2008

Jeynes, W. H. (2003). A meta-analysis: The effects of parental involvement on minority children's academic achievement. Education and Urban Society, 5(2), 202-218. doi:10.1177/0013124502239392

Kao, G. (2004). Parental influences on the educational outcomes of immigrant youth International Migration Review, 38, 427-450. doi:10.1111/j.17477379.2004.tb00204.x

Kim, E. (2002). The relationship between parental involvement and children's educational achievement in the Korean immigrant family. Journal of Comparative Family Studies, 33(4), 529-540. doi:10.3138/jcfs.33.4.529

Kirsch, C. (2012). Ideologies, struggles and contradictions: An account of mothers raising their children bilingually in Luxembourgish and English in Great Britain. International Journal of Bilingual Education and Bilingualism 15(1), 95-112. doi:10.1080/13670050.2011.607229

Kompiadou, E. (2013). Pedagogiki axiopiisi tis glosikis ke politismikis eterotitas sto nipiagogeio. [=Pedagogical utilization of linguistic and cultural diversity at kindergarten]. (Master's thesis). Aristotle University of Thessaloniki, Greece.Retrieved from http://ikee.lib.auth.gr/record/134256/files/GRI-201412281.pdf?version=1 [In Greek]

Kompiadou, E., Gkaintartzi, A., Panagiotidou, C., Tsokalidou, R., Tsioumis, K., \& Petrogiannis, K. (2018). Pedagogical utilization of linguistic and cultural diversity at kindergarten: a case study in Greece. In C. Aguiar \& C. Silva (Eds.), Case studies on curriculum, pedagogy, and social climate interventions tackling inequalities (pp. 57-87). Inclusive education and social support to tackle inequalities in society. ISOTIS project report (H2020-SC6-REV-INEQUAL). doi:10.1080/1350293x.2020.1707363

Levels, M., Dronkers, J. \& Jencks, C. (2014). Mind the gap. Compositional, cultural and institutional explanations for numeracy skills disparities between adult immigrants and natives in Western countries. Harvard University, John F. Kennedy School of Government, HKS Working Paper No. RWP14-020. Retrieved from https:/ / papers.ssrn.com/sol3/papers.cfm?abstract_id=2449635

Magos, K. (2005). Prosegizontas ton alo: ekpedevsi enilikon ke diapolitismiki ikanotita [Approaching the other: adult education and intercultural competence]. In Karalis, Th. et al. (Eds), Adult Education and Social Skills. Conference proceedings of $2^{\text {nd }}$ International Conference: (pp 199-209). Athens: Scientific Committee of Adult Education [In Greek]. Retrieved from https:// blogs.sch.gr/kkiourtsis/files/2011/06/praktika-synedriou-EEEE.pdf

Magos, K., \& Simopoulos, G. (2009). "Do you know Naomi?" Researching the intercultural competence of teachers teaching Greek as a second language in immigrant classes. Intercultural education, 21(1), 255-265. doi:10.1080/14675980903138616

Martinez, C. R., Jr., DeGarmo, D. S., \& Eddy, J. M. (2004). Promoting academic success among Latino youth. Hispanic Journal of Behavioral Sciences, 26(2), 128-151. doi:10.1177/0739986304264573 
Mary, L., \& Young, A. (2017) Engaging with emergent bilinguals and their families in the pre-primary classroom to foster well-being, learning and inclusion. Language and Intercultural Communication 17(4), 455-473. doi:10.1080/14708477.2017.1368147

Nauck, B., \& Schnoor, B. (2015). Against all odds? Bildungserfolg in vietnamesischen und türkischen Familien in Deutschland. KölnerZeitschriftFürSoziologie Und Sozialpsychologie, 67(4), 633-657. doi:10.1007/s11577-015-0345-2

OECD. (2015). Skills for Social Progress: the power of social and emotional skills. Paris: OECD Publishing. doi:10.1787/9789264226159-6-en

Pauwels, A. (2005). Maintaining the community language in Australia: Challenges and roles for families. The International Journal of Bilingual Education and Bilingualism 8(2-3), 124-31. doi:10.1080/13670050508668601

Penderi, E., \& Petrogiannis, K. (2013). Sindesi sxoliou - ikogenias ke to zitima tis metaxi tous sinergasias: kritiki parousiasi vasikon theoritikon modelon $\{=$ School family connection and the issue of their cooperation: Critical presentation of main theoretical models\}. [In Greek]. Hellenic Journal of Research in Education 1(1), 2-26. doi:10.12681/hjre.8790

Petrogiannis, K., \& Penderi, E. (2014). The Quality of Parent-Teacher Relationship Scale in the Kindergarten: A Greek Study. International Research in Education, 2(1), 1-21. doi:10.5296/ire.v2i1.4343

Riederer, B., \& Verwiebe, R. (2015). Changes in the Educational Achievement of Immigrant Youth in Western Societies: The Contextual Effects of National (Educational) Policies. European Sociological Review, 31(5), 628-642. doi:10.1093/esr/jcv063

Ryan, G., \& Bernard, R. (2000). Data management and analysis methods. In N. Denzin \& Y. Lincoln (Eds.), Handbook of Qualitative Research (2nd ed., pp. 769-802). Thousand Oaks, CA: Sage.

Tsokalidou, R. (2012). Horos gia dyo. Zitimata diglossias ke ekpedefsis [Space for two. Issues of bilingualism and education]. Thessaloniki: Zygos. [In Greek]

Tsokalidou, R. (2017). SiДаYes.Beyond bilingualism to translanguaging. Athens: Gutenberg [Bilingual, Greek \& English].

Vasileiadis, K., Kompiadou, E., Tsioumis, K., \& Petrogiannis, K. (2020). A Multicultural Citizenship Education Program Through a Virtual Learning Environment Platform: A Greek Study Under the EU ISOTIS Project. International Journal of Learning and Development, 10(1), 52-68. doi:10.5296/ijld.v10i1.16041

Yin, R. K. (2003). Case study research: Design and methods (3rd ed.). Thousand Oaks, CA: Sage.

Zambeta, E., Askouni, N., Androusou, A., Leontsini, M., Papadakou, Y., \& Lagopoulou, V. (2019). Refugees in the Greek educational context. In E. Zambeta et al., (Eds), Democratic school governance for inclusion: a whole community approach" (pp. 1734). Report produced in co-operation with Bulgaria, Greece, Hungary, Montenegro, Poland and Romania. Council of Europe. Retrieved from https://rm.coe.int/publication-democratic-school-governance-for-inclusionweb/168094e6e8 